\title{
Pricing and reimbursement of innovative pharmaceuticals in France and the new healthcare reform
}

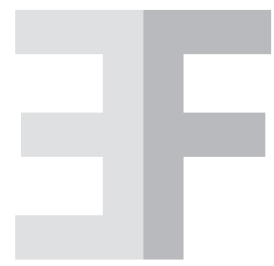

REVIEW

\author{
Alexander Natz ${ }^{1}$, Marie-Geneviève Campion ${ }^{1}$ \\ European Confederation of Pharmaceutical Entrepreneurs (EUCOPE), Brussels, Belgium
}

\begin{abstract}
Over the last years, many cost-containment measures were implemented by the government leading to drastic price-cuts. New paradigms and healthcare models are emerging and health technology assessments are increasingly taken into consideration. France has the second biggest rank in terms of healthcare spending after the US. Pharmaceuticals represented around $19 \%$ of the budget of the Health Insurance funds in 2009. In France, innovative pharmaceuticals have been subject for a long-time to price-control and cost-containment measures. The present review provides a general description of the French health care system, analyzing the developments and changes by the recent French health care reform.
\end{abstract}

Keywords

French healthcare reform; Pricing; Reimbursement; Innovative pharmaceuticals

\section{INTRODUCTION}

The French system for pricing and reimbursement for pharmaceutical innovation has been influential for the new German system of Early Benefit Assessment under $\S$ 35a SGB V and for the new mandatory price negotiation for all innovative pharmaceuticals under paragraph $130 \mathrm{~b}$ of the Sozialgesetzbuch V (SGB V). The following review describes the French system in general and analyses the developments and changes by the recent French healthcare reform. Innovative pharmaceuticals in France have been subject for a long-time to price-control and cost-containment measures. France initiated a concept of an evaluation of medical benefit by cost-containment bodies and mandatory price negotiations even in 2004 when Germany was still abandoning the concept of price negotiation. While Germany copied part of the French system of price negotiation, it has not enacted any direct restriction on the volume of sales in the AMNOG reform.

France has the second biggest rank in terms of healthcare spending after the US. Pharmaceuticals represented around $19 \%$ of the budget of the Health Insurance funds in 2009 [1]. The average ratio of health spending to GDP was around $11.2 \%$ in 2008 [2] for a population of 65.8 million inhabitants. Markets are to be divided between hospital and pharmacy markets and special rules apply to innovative pharmaceuticals in both markets. In this regard, the growth by around $1.3 \%$ of the spending on pharmaceuticals expressed in manufacturer's price excluding VAT in 2010 was mainly driven by hospital medicines purchases $(+6 \%)$. In the same time, the manufacturer's price excluding VAT of reimbursable pharmaceuticals sold in pharmacies increased by $0.5 \%$ compared to 2009 [3].

Over the last years, many cost-containment measures were implemented by the government leading to drastic price-cuts. New paradigms and healthcare models are emerging and health technology assessments are increasingly taken into consideration. The Debré-Even [4] report following the Mediator controversy and the consultation process on medicinal products (so-called Assises du Médicament [5]) were the basis for an extensive reform aiming at fostering safety reporting on medicinal products and medical devices. The reform consists of three pillars which are the prevention of conflicts of interests and the transparency of decisions, the regulation of off-label use and the promotion of better trained and informed health professionals.
Corresponding author Dr. Alexander Natz, LL.M. Bundesverband der Pharmazeutischen Industrie e.V. (BPI) Rue du Commerce 31 1000 Brussels (Belgium) anatz@bpi.de

\section{Disclosure}

The authors have no financial competing interest to declare 


\section{THE PHARMACY MARKET}

\section{Institutional framework}

\section{Central and independent regulatory bodies, the ANSM (ex-AFSSAPS) and the CEPS}

Among the main institutional stakeholders, the French Health Products Safety Agency [6] (Agence Française de Sécurité Sanitaire des Produits de Santé, AFSSAPS) which is under supervision of the French Health Ministry [7] is responsible for marketing authorizations, pharmacovigilance of national authorized pharmaceuticals and inspections. The recent healthcare reform which was enacted on the $29^{\text {th }}$ December 2011 provides among other things to change the name of the AFSSAPS into the National Agency for Medicines Safety (Agence Nationale de Sécurité du Médicament, ANSM). The ANSM will be financed through taxes and charges from the pharmaceutical industry.

The Healthcare Products Pricing Committee [8] (Comité Economique des Produits de Santé, CEPS), which consists of officials from different ministries (Health, Social Security, Competition and Industry) [9] and health insurance funds, is in charge of the pricing of pharmaceuticals for human use [10]. Its missions are to negotiate in line with the ministerial policy a Framework Agreement (Accord-cadre) with the pharmaceutical industry [11] and to set prices. It is also entitled to sign with each pharmaceutical company or group of companies a contractual agreement for a period of maximum 4 years determining e.g. the retail price of the pharmaceutical and the price trend, the possible rebates as well as the commitments of the company to promote a good use of the pharmaceutical and to respect sales volumes. It also provides for the conditions and modalities regarding pharmaco-epidemiological post-authorization studies [12].

\section{Bodies created by the last healthcare reforms, the HAS and the UNCAM}

The healthcare insurance reform of 2004 [13] brought comprehensive changes in the institutional framework of pricing and reimbursement decisions. It created more cohesion between the government's pricing decision and reimbursement policies and strengthened the role of the CEPS in this regard. Two new institutions were created, the French National Authority for Health (Haute Autorité de Santé, HAS) [14] and the National Union of Health Insurers (Union Nationale des Caisses d'Assurance Maladie, UNCAM) [15].

The HAS [16] is an independent public body. Its missions range from providing health regulatory authorities with proper information for price setting based on scientific expertise to encouraging good practices and the proper use of pharmaceuticals. In this regard, the HAS cooperates on a regular basis with the IQWIG in Germany [17] and the NICE in the United-Kingdom [18] regarding the exchange of good practices and the sharing of health technology assessment studies [19]. Within the HAS, the Transparency Commission (Commission de la Transparence) [20] is composed of independent scientists and is in charge of assessing pharmaceuticals on the basis of a scientific medico-economic and public health assessment [21]. It assesses in depth the medical benefit of pharmaceuticals (Service Médical Rendu, SMR) and the innovation level by assessing the improvement of the medical benefit (Amélioration du Service Médical Rendu, ASMR) compared to alternative products [22]. HAS can thus be compared to the German IQWIG.

The other institution created by the healthcare reform of 2004 is the UNCAM [23] which unites the main health insurance funds, especially the biggest payer, the main regime for public and private employees (Caisse Nationale d'Assurance Maladie des Travailleurs Salariés, CNAMTS [24]). The UNCAM is also in charge of the reimbursement policy and determines the products to be reimbursed and their respective reimbursement rate. UNCAM can thus be compared to the GKV-Spitzenverband in Germany.

The healthcare reform "Hospital, Health, Patients and Territories" of 2009 created a new kind of local stakeholder, the Health Regional Agencies (Agences Régionales de Santé, ARS) which role is to steer and implement national healthcare policies in regions.

\section{Major stakeholder associations}

Pharmaceutical companies which are represented by the LEEM [25] as well as physicians and pharmacists grouped in professional organizations (respectively in the Ordre des Médecins [26] and the Ordre des Pharmaciens [27]) are also important in the legislative process [28]. For example the LEEM sets out the general framework together with the CEPS for sales growth pricing and the promotion of medicinal products.

\section{Legislative and regulatory framework}

\section{Link between the pricing-procedure and the reimbursement status}

The pricing procedure which is linked to the reimbursement status of the pharmaceutical is set out in the Social Security Code. The law provides that pharmaceuticals without 
any ASMR rating or implying no savings on medical treatment costs are not reimbursed by health insurance funds. Their price can be set freely but the reimbursement by the health insurance funds is prohibited [29]. The general price negotiation scheme for pharmaceuticals with an ASMR goes through different stages [30]. The pricing-process begins with pharmaceutical companies submitting their applications simultaneously to both the CEPS and the Transparency Commission.

The price fixing decision of the CEPS considers the medicines market in a comprehensive way. It takes into account the direct and indirect consequences of the price of the pharmaceutical on price structures within a single group and among different therapeutic groups, the economic consequences associated with reimbursement for the health insurance funds [31] and the long-term consequences for future pharmaceuticals with the same indication [3].

In practice, the ex-factory price set by the CEPS is based on the ASMR rating granted by the Transparency Commission, the expected sales of the pharmaceutical and the prices of pharmaceuticals in other EU Member States (external reference pricing) as well as the price of possible alternative therapies in France.

ASMR ratings are grouped in 5 main classes:

- ASMR I rating is granted for medicinal products bringing a major therapeutic value;

- ASMR II for medicinal products representing a significant improvement in terms of efficacy and/or reduction of adverse effects compared to existing alternatives;

- ASMR III for a modest improvement;

- ASMR IV rating for a minimum improvement;

- ASMR V for medicinal products without any therapeutic value but still being recommended to be registered on the positive list for reimbursement with a price criterion which does not lead to any nonjustified expenses.

Regarding external reference pricing, no formal procedure exists. Pharmaceutical companies are requested to provide the price of the pharmaceutical in question in other EU member states so that prices stay in line with the average price in the EU.

After the CEPS took its decision regarding the price, it formulates a proposal which is then negotiated with the pharmaceutical company. For pharmaceuticals having been granted an ASMR rating at least equal to level IV, the CEPS is committed to make the pharmaceutical company a proposal for a convention within 75 days after the assessment of the Transparency Commission [32]. In case of a rejection by the pharmaceutical company, the CEPS is obliged to examine the counter-proposal [33]. The ex-factory price is set by means of a contract which is signed for 4 years between the CEPS and the pharmaceutical company [34]. In case the negotiations fail, the price is set by decree of the ministers for Social Security, Health and Economy. CEPS is thus a powerful and crucial decision maker for pricing in France. Even though CEPS' decision depends on the ASMR rating, it has a wide discretion regarding the first pricing proposal. This means by contrast that - like in Germany - the negotiation power of the pharmaceutical company is limited.

For innovative pharmaceuticals with an ASMR IV and I to III rating, the article 4 of the Framework Agreement provides for a period of 5 years that the price level will not be lower than the price level in the four main countries: Germany, Italy, Spain and the U.K. Medicines having been granted an extension of indication with an ASMR rating from I to III and pediatric medicines which have realized studies based on a pediatric investigation plan benefit from an extension of one year. Those measures aiming at promoting transparency and incremental innovation do not include all products with an ASMR IV.

\section{Fast-track procedure of price notification for innovative pharmaceuticals}

A special fast-track-procedure of notification for innovative pharmaceuticals is provided by law since 2003 [35] in order to facilitate their pricing and reimbursement process.

The Framework Agreement considers as innovative pharmaceuticals with an ASMR I, II and III rating and IV under some strict conditions [36]. In this fast-track procedure, right after the granting of the ASMR by the Transparency Commission, the manufacturer proposes a price that is de facto accepted if the CEPS does not object it within two working weeks. The convention is then signed within 48 hours. Otherwise, the normal application procedure applies. The price notified by the manufacturer should be in line with the existing price in Italy, Germany, Spain and the United-Kingdom. At the same time, pharmaceutical companies also commit to certain conditions concerning price revision, sales volumes, studies and information sharing related to the pharmaceutical product [37]. However, this procedure is not frequently used in practice and corresponds to a narrow definition of innovative pharmaceuticals 
[38]. In 2010, two orphan drugs applied for the price notification and both were refused. In 2009, 3 pharmaceuticals applied for the price notification procedure. Only one, which had an ASMR IV rating and has a use which does not imply any additional cost compared to existing pharmaceuticals, was accepted.

\section{The reimbursement procedure}

After the agreement between the CEPS and the pharmaceutical company on the ex-factory price, the registration of pharmaceuticals on the positive list of reimbursable pharmaceuticals [39] is decided on by the UNCAM, based on the SMR rating granted by the Transparency Commission [40]. The registration, which is published in the Official Journal, is valid for 5 years. After this period the SMR rating of the pharmaceutical is reassessed.

Corresponding to those SMR rating, four reimbursement rates $(100 \%, 65 \%, 30 \%$ and $15 \%$ ) have been defined. Full reimbursement is granted for pharmaceuticals which are identified as irreplaceable (signalized by a white crossed sticker) and for patients having a medical treatment for a disease which is fully reimbursed [41].

\section{Claw-back payments, price review clauses and conventional policy}

While the final price of pharmaceuticals sold in pharmacies includes the fixed margin of the wholesalers and of the pharmacists as well as a VAT rate of $2.1 \%$, the price set by the CEPS also varies due to claw-backs, price review clauses and contractual agreements.

\section{Claw-back per pharmacotherapeutic class based on capped turnover}

The Framework Agreement provides annual adjustments if sales of pharmaceuticals exceed the national objectives on healthcare spending (Objectifs nationaux des Dépenses d'Assurance Maladie, ONDAM) defined each year in the Social Security Financing Law (Loi de Financement de la Sécurité Sociale, LFSS), the so-called "safeguard clause" [42]. Hereby claw-backs apply if the cumulative growth of sales of reimbursable pharmaceuticals exceeds the sales-weighted mean value of the "K" [43] growth rate defining the ceiling of the safeguard clause.

At the end of the year, pharmaceutical companies must send to the CEPS a declaration which sums up the volume and actual turnover of sales for each medicinal product and pharmaceutical form. Quantitative clawbacks consist of payments per pharmacotherapeutic class grouping and of payments based on the turnover of the firm.

Specific provisions are provided for innovative pharmaceuticals [44]. Pharmaceuticals having been granted an ASMR I and II rating are exempted from claw-back for respectively 36 and 24 months. ASMR III and IV rating have a respective $50 \%$ and $25 \%$ exemption for 24 months.

\section{Price review clauses}

Price review clauses are also foreseen in France [45]. Two main price review clause categories exist. The first one, "daily treatment clauses", covers situations where time and usage do not confirm the assumptions made when setting the price of the pharmaceutical. It results that the real cost per patient is inconsistent with the one that was agreed between the CEPS and the company. The second situation corresponds to "volume clauses" which ensure that the volumes of the pharmaceutical sold stay in line with the established target patient group assumed [3]. Additionally to the price review clauses, prices may be reviewed at the initiative of the CEPS when the registration of the medicine is being renewed, when the growth spending for a pharmaceutical is not consistent with the ONDAM [46] or when scientific and epidemiological data in follow-up studies on real-life change significantly.

\section{Conventional policy aimed at physician prescription}

Introduced in the LFSS 2008 and developed by the UNCAM [47], the contract for the improvement of individual practices (Contrat d'Amélioration des Pratiques Individuelles, CAPI) is a voluntary incentive scheme designed among others to control physicians' prescription behavior [48]. The CAPI scheme aims at promoting diseases preventions, optimizing prescription of generic medicines and promoting less costly medicines demonstrating an equal efficiency (e.g., antibiotics, statins, antihypertensive medicines, protonpump inhibitors, antidepressants and ACE inhibitors) [49]. A CAPI is signed for 3 years and can be terminated at anytime. Intermediary and final targets are common for all physicians but the remuneration of each physician depends on his initial prescribing situation and the annual progress with regards to the targets [50].

\section{THE HOSPITAL MARKET}

\section{Institutional framework}

Before 2004, prices for hospital pharmaceuticals were set freely and were principally influenced by the volume bought by the hospital and its buying power. The LFSS law of 2004 [51] changes this situation and the framework of the "Plan Hôpital 2007" [52] still sets out 
the main lines regarding the regulation of hospitals. The aim was especially to regulate the price of innovative medicines and hospital ambulatory medicines meaning medicines intended to be delivered to outpatients (so called médicaments rétrocédés) [53].

In this regard, the modalities regarding the price-setting of innovative medicines and hospital ambulatory pharmaceuticals have been defined in the hospital medicines Framework Agreement which was signed by the CEPS and the LEEM on the March, 30 2004 and then merged with the general Framework Agreement on September, $25^{\text {th }} 2008$.

\section{Legislative and regulatory framework for pricing and reimbursement}

Pricing of hospital pharmaceuticals differs from pharmaceuticals dispensed in pharmacies once the assessment of the Transparency Commission has been issued. In the new general framework, the price of hospital medicines is set freely between the hospital and pharmaceutical company. Funding for hospitals and reimbursement for hospital pharmaceuticals is based on an activity-based payment (Tarification à l'activité, T2A) by means of diagnosis related groups (Groupes homogènes de séjour, GHS) [54]. However, the Framework Agreement provides that pharmaceutical companies have to declare the hospital price they plan as well as the hospital price of the medicines in the main EU member states.

Three categories of hospital pharmaceuticals exist with a special price and reimbursement framework: hospital ambulatory medicinal products, innovative medicines and pharmaceuticals having been granted an Authorization of Temporary Usage (Autorisation Temporaire d'Utilisation, ATU).

\section{Framework for hospital ambulatory medicinal products}

In order to be delivered to outpatients, hospital pharmaceuticals have to be registered on the list of retrocession [55]. Pharmaceutical firms must submit the ex-factory price to the CEPS [56]. The CEPS may oppose to the company's submitted price [57]. The submitted price may be too high compared to the price in the four main European countries or compared to the existing comparable alternatives in France. Opposition may also be on the grounds of the insufficiency of the commitments of the firm with regards e.g. to the quantities sold or the conditions given the marketing authorization indications. The final price of hospital ambulatory pharmaceuticals is made of the ex-factory price which is adjusted by the VAT and by a flat-rate markup to compensate for the costs of hospital pharmacies [58].

The reimbursement of hospital ambulatory pharmaceuticals is based on the public final price [59]. Incentives are given to hospitals to acquire pharmaceuticals to a lower price. If the price paid by the hospital is lower than the public final price, the gain is for the hospital. Therefore, public tenders and buying power situations could increasingly become an issue in France in addition to abovementioned cost-containment measures.

\section{Framework for certain innovative medicines reimbursable on top of the T2A}

For certain innovative pharmaceuticals, especially orphan and pediatric drugs, pharmaceutical firms must declare the price to the CEPS [60]. The pricing system of those pharmaceuticals differs significantly from other hospital pharmaceuticals and is derived to large extent from the system for pricing of innovative pharmaceuticals dispensed in pharmacies. Full reimbursement is granted on the basis of the public price provided the hospital legal representative signed a contract of good use (Contrat de Bon Usage, CBU) with the ARS [61].

In case of violation of the contract, the reimbursement may be lowered by $30 \%$ [62]. In any case the difference between the sum paid and the amount reimbursed to the hospital cannot be paid out-of-pocket by the patient. If the price paid by the hospital is lower than the submitted price, the gains are divided between the hospital and the health insurance funds.

\section{Specific framework for medicines with an Authorization of Temporary Usage (ATU)}

Autorisation Temporaire d'Utilisation (ATU) corresponds to an exceptional and temporary measure granted by the AFSSAPS for the treatment of serious or rare diseases in the absence of a suitable therapeutic alternative with a marketing authorization available in France when a positive benefit/risk ratio is assumed [63]. For a product with an ATU a marketing authorization does not exist. These pharmaceuticals may be authorized abroad or be still under development. An ATU can be intended for a single, named patient (so called "named-patient ATU") or it can concern a group of patients, treated and monitored according to a protocol for therapeutic use and information collection (so-called "cohort ATU").

While only hospitals pharmacies belonging to public or private health care institutions 
are authorized to supply ATU pharmaceuticals, those medicines may be intended for exclusive use in hospital ${ }^{1}$ or may be sold to ambulatory patients. In this regard, nominative ATU products are deemed to be sold by hospital pharmacies to ambulatory patients. Cohort ATU products have to be registered on the retrocession list.

In both cases, the maximum price of pharmaceuticals with an ATU must be submitted by the pharmaceutical company to the CEPS which makes these declarations public [64]. For medicines with an ATU which are intended for hospital use only hospitals receive compensation through special endowments. Products with an ATU which are sold to ambulatory patients are fully reimbursed on the basis of their final price.

\section{THE BENEFIT ASSESSMENT OF INNOVATIVE PHARMACEUTICALS}

\section{Focus on the ASMR and SMR rating}

Key-criteria in setting the price and determining the reimbursement rate of pharmaceuticals are the SMR and ASMR ratings given by the Transparency Commission that assesses the medical benefit and the innovation rate of the pharmaceutical. The level of those ratings is the basis of the reimbursement status and the price of the pharmaceutical.

\section{The SMR rating}

The SMR rating is used to determine the reimbursement level for a pharmaceutical [65]. It takes into account the efficacy of the pharmaceutical under assessment and its side effects, the characteristics of the disease it is indicated for, the existence of alternative therapies, the role of the pharmaceutical within the overall therapeutic strategy as well as the impact on public health [66]. According to the assessment of those criteria, different levels of SMR rating have been defined: major or important therapeutic value, moderate or low therapeutic value but enabling reimbursement and insufficient [67]. The SMR rating of a pharmaceutical is granted for 5 years. In 2010, 89 SMR ratings have been granted among which $88 \%$ were of major, moderate or low therapeutic value [68].

After 5 years, the SMR of a pharmaceutical is reevaluated through the new data which have been gathered [69]. The AFSSAPS started reassessing in September 2011 the benefit/risk ratio of each medicinal product having been

Exclusive use in hospital means that prescription, supply and administration of the medicines are carried out only within a health care institution granted a marketing authorization prior to 2005 [70]. To that purpose, it defined an approach to determine the medicines to be reassessed with priority. The entry in the process can be the result of either a signal of risk or loss of benefits, a renewal of the marketing authorization or of a systematic approach according to automate and manual criteria ${ }^{2}$.

\section{The ASMR rating}

Primary consideration for price-setting is the ASMR of the pharmaceutical. Contrary to the SMR rating, the ASMR rating compares the therapeutic value of a pharmaceutical to the existing alternatives in the same therapeutic class and assesses the improvement brought. In $2010,40 \%$ of the medicinal products assessed were granted an ASMR rating between I and IV. In particular, two medicinal products were granted an ASMR I rating, two an ASMR II, eight an ASMR III and twenty an ASMR IV rating [68].

\section{Insights into the medico-economic evaluation of the HAS}

The Economic and Public Health Commission of the HAS (Commission Evaluation Economique et Santé Publique, CEESP) was created on July, $1^{\text {st }} 2008$ [71]. The CEESP regroups 25 members from various disciplines and its missions are to bring an expertise for economic studies and to propose decisions to the HAS regarding e.g. the validation and diffusion of recommendations and medicoeconomic opinions [72]. The main activities of the CEESP relate to the assessment of public policies (assessment of the benefits, risks and efficiency) and medico-economic assessment [73].

Three intervention levels have been defined by the CEESP to reinforce the efficiency of health strategies [74]. The first level consists in comparing two products for the same indication. If their efficiency and tolerance is the same, it will recommend the less expensive one. The second level which is implemented when a difference in terms of efficiency or tolerance exists, concerns a balancing of the benefit and costs of the respective pharma-

\footnotetext{
Automate criteria include medicines on the French market for at least 7 years, with a low or insufficient SMR, with a galenic form liable to result in an additional risk because of its particular bioavailability and medicines with a high or a very low sales volume. With regards to manual criteria, they require specific research about each medicine such as for example whether it has been withdrawn from the market in another European country, or whether it is associated with an identified or a potential risk. Each criterion is assigned a weighting. After having assessed each medicinal product in the light of each criterion, the AFSSAPS assigns each of the products a weighted score. Medicines with a higher score will be reassessed with priority. The finalization of the criteria and the screening started in September 2011
} 
ceuticals. Finally, the third level corresponds to a "full" analysis" in which the efficiency and the associated costs of a product as well its organizational or ethical dimensions are taken into account. In this regard, a public consultation was launched from December 2010 to January 2011 in order to explain the methods and process of the economic assessment of the HAS which is essentially a comparative approach [75]. In 2010, it released 18 medical assessments and 6 public health recommendations [68]. The LFSS 2012 provides in this regard that when the pricing committee does not take into account the assessment of the HAS while setting the price of a pharmaceutical, it has to justify its decision [76].

\section{Challenges with actual price-setting for innovative pharmaceuticals}

\section{Price-cut and price limitation for innovative products}

The CEPS recently gave a clear signal for a price-stop for certain pharmaceuticals. While it was common practice to give pharmaceuticals having been granted a high ASMR rating a price advantage compared to the existing alternatives, the CEPS clearly signified that for expensive medicines additional costs for the health insurance funds were neither justified nor necessary as the access to market was sufficiently rewarding by itself [3]. In a speech hold in January 2012, Gilles Johanet, Chairman of the CEPS, explained that the savings of around 1 billion planned for 2012 should not be reached through new price-cuts but by the limitation of the prescription of expensive products and via a logic of performance and cost-containment in particular in the hospital sector [77].

The article 10bis of the Framework Agreement already provides that the CEPS can oblige a pharmaceutical company commercializing an orphan drug with annual costs per patient over 50,000 Euros, in return for a price which is internationally coherent, to treat all the patients entitled for the treatment without any restriction, for a fixed total-turn-over.

\section{New economic paradigm for innovative pharmaceuticals}

While the law provides a fast-track procedure of price notification for innovative pharmaceuticals, the practice shows that only a limited amount of products from 1 to 3 per year only are concerned [3].

Through different incentives frameworks, health regulatory authorities send signals to pharmaceutical companies about the products they want to encourage, and the disease areas they want to give priority [78]. In the new approach of the CEPS, an innovation does not imply high prices anymore. In this regard, N. Renaudin, who was the previous chairman of the CEPS, declared in 2009 that prices should stop increasing, especially for orphan drugs. For him, pharmaceuticals which are considered as too costly should not be marketed [79].

The LFSS 2011 provides that medicines treating rare diseases with a turn-over exclusive of tax over 30 million Euros are not exempted anymore from the wholesalers' tax, safeguard clause tax and promotion tax [80].

\section{IMPACT OF THE REFORM ON THE STRENGTHENING OF THE SAFETY OF MEDICINES AND HEALTH PRODUCTS}

The Mediator controversy which led to the publication of the Debré-Even report ${ }^{3}$ was the starting-point for an extensive reform which aims at fostering safety of medicines and health products and has an impact on the price and reimbursement framework of innovative medicines in France.

\section{Impact on the ATU system}

With regard to the ATU system [81], the healthcare reform provides that an ATU application has to be accompanied by a simultaneous demand for a marketing authorization or by an application for a cohort ATU or by clinical studies with the medicine for the same indication in France. ATU are granted for a limited period of time which can be renewed. Exceptions from these requirements are provided for particularly in cases where, under the current state of the therapeutic options available, serious consequences for the patients are highly likely or, when the medicinal product is no longer commercialized for a specific indication and there is a strong presumption that the product is efficient and safe for a different indication. The healthcare reform also introduces a mandatory systematic monitoring of patients regarding the tolerance and the efficacy of the product.

\section{Impact on the off-label use}

The healthcare reform strengthens regulation of off-label use which should be subject to

\footnotetext{
The "Rapport de la mission sur la refonte du système français de contrôle de l'efficacité et de la sécurité des médicaments" [4] recommends a fundamental reform of the AFSSAPS which would be in charge of the Transparency Commission. The HAS would focus on its mission of defining global health strategies and regulating medical activity. It also recommends moving from the SMR rating for new molecule towards the ASMR rating so that medicines should be exclusively assessed by clinical comparison with an existing molecule
} 
the approval of the health authorities [82]. Off-label use prescription is authorized in the absence of other alternatives, which means no marketing authorization or ATU available, under the conditions that either a Recommendation of Temporary Usage (RTU) ${ }^{4}$ for a period of no more than three years has been granted by the ANSM for the indications or the conditions of clinical use, or the prescriber judges it indispensable to improve or stabilize the patient's condition. Modalities for the RTU will be set later by decree.

The reform also provides for a monitoring of the patient, a mandatory application for an extension of indications or a modification of the marketing authorization in a given timeline and an obligatory mentioning of the offlabel use on the prescription.

Concerning the reimbursement of off-label medicinal products [83], when no appropriate alternative is available, medicinal products for the treatment of a chronic or orphan disease subject to a RTU are by way of exception reimbursed for a limited time.

\section{Impact on visits by pharmaceutical representatives at hospital}

The healthcare reform sets limits to visits of the pharmaceutical representatives at hospitals [84]. For an experimental period of no longer than 2 years collective visits by pharmaceutical representatives at hospitals are allowed only before several healthcare professionals. The conditions should be laid down by a convention signed between each healthcare facility and each pharmaceutical firm. Practical modalities for the convention will be set by a decree of the Health Minister after a favorable opinion of the High Authority for Health (HAS) which should be issued before August 2012.

Exceptions are provided for restricted medical prescription (hospital only medicines,

\footnotetext{
4 The RTU shall contain information concerning the efficacy, the actual conditions of use and the adverse effects under conditions to be specified by a future decree
}

hospital prescription medicines, medicines with initial hospital prescription or not) ${ }^{5}$ and for medical devices.

Financial penalties in case of non-compliance are foreseen. The pricing committee can decide to set annual numerical targets regarding the evolution of those practices, if necessary per ATC class or for certain pharmaceuticals. Depending on the outcome of an assessment report in January 2013 at the latest, the system of limited visits of sales reps may be extended timewise and to the field of ambulatory medicines.

\section{FOR A BETTER EVALUATION OF THE VALUE OF INNOVATIVE PHARMACEUTICALS}

It is important that EU member states do not adopt a fragmented approach on the relative effectiveness of pharmaceuticals but ensure that innovation is properly taken into account when establishing the value of innovative pharmaceuticals. In this regard, risk-sharing arrangements between the healthcare system and pharmaceutical companies are emerging and can contribute to promote the competitiveness of pharmaceutical companies while containing costs for national budgets.

The new paradigms redefine the role played by the different stakeholders, create new stakeholders and tend to normalize the medical practice. However policy regarding price and reimbursement should stay consistent and reliable for pharmaceutical companies [85]. Only under these circumstances pharmaceutical companies can decide on strategic decisions related to R\&D and capital investment [86].

\section{ACKNOWLEDGEMENTS}

Reference is made to the publication in PharmInd 2012 page $582 \mathrm{ff}$. 5 Medicinal products with restricted medical prescription are
mentioned in the art. R.5121-77 of the Public Health Code

\section{REFERENCES}

1. CNAMTS, Data 2009. Available at www.ameli.fr [last accessed May 2012]

2. OECD Health Data, 2010. Available at http://www.oecd.org/document/11/0,3343, en_21571361_44315115_45549771_1_1_1_1,00.html [last accessed May 2012]

3. CEPS Annual Report 2010, July 2011. Available at http://www.sante.gouv.fr/IMG/pdf/Rapport_annuel_2010_Final. pdf [last accessed May 2012]

4. Rapport de la mission sur la refonte du système français de contrôle de l'efficacité et de la sécurité des médicaments. http://www.ladocumentationfrancaise.fr/rapports-publics/114000141/ [last accessed May 2012]

5. http://www.sante.gouv.fr/assises-du-medicament,8167.html [last accessed May 2012] 
6. http://www.afssaps.fr/ [last accessed May 2012]

7. Law n. 98-535 of July, 1st 1998, Art. 5 to 8, http://www.legifrance.gouv.fr/affichTexte.do?cidTexte=JORFTEXT0 $00000573437 \&$ dateTexte $=[$ last accessed May 2012]

8. http://www.sante-sports.gouv.fr/comite-economique-des-produits-de-sante-ceps.html [last accessed May 2012]

9. Art. D162-2-1 modified by Decree n. 2010-71 of March, 15th 2010, http://www.legifrance.gouv.fr/affichCodeArticle.do?cidTexte=LEGITEXT000006073189\&idArticle=LEGIARTI000021989401\&dateTexte=20100913 [last accessed May 2012]

10. Law n. 2004-810 of the August, 13th 2004, http://www.legifrance.gouv.fr/affichTexte.do?cidTexte=LEGITEXT0 $00005824192 \&$ dateTexte $=20100913$ [last accessed May 2012]

11. The Framework Agreement was signed on September, $25^{\text {th }} 2008$ and amended by the riders on October, $26^{\text {th }} 2009$ and on the $7^{\text {th }}$ of October 2010, by the CEPS and the LEEM ("les Entreprises du Médicament") which is the pharmaceutical companies' trade association in France, http://declaration-retrocession.fr/doc/Accord_cadre_fusionne_250908.pdf [last accessed May 2012]. It covers i.a. sales growth, pricing and promotion. It is likely to be renegotiated starting from March 2012.

12. Art. L162-17-4 of the Social Security Code, modified by the law n ${ }^{\circ 2009-879}$ of July, $21^{\text {st }} 2009$, http://www.legifrance.gouv.fr/affichCodeArticle.do?cidTexte=LEGITEXT000006073189\&idArticle=LEGIARTI000017828253 \&dateTexte [last accessed May 2012]

13. Law n. 2004-810 of August, 13 ${ }^{\text {th }}$ 2004, Title 2, Section 1, Art. 35, 36 et 37, http://www.legifrance.gouv.fr/affichTexte. do?cidTexte=JORFTEXT000000625158 [last accessed May 2012]

14. Decree n. 2004-1139 of October, 26 th 2004, http://www.legifrance.gouv.fr/affichTexte.do?cidTexte=JORFTEXT 000000445632\&dateTexte [last accessed May 2012]

15. Decree n. 2004-1075 from October, 12 th 2004 , http://www.legifrance.gouv.fr/affichTexte.do?cidTexte=JORFTEX T000000256840\&dateTexte [last accessed May 2012]

16.http://www.has-sante.fr/portail/jcms/j_5/accueil [last accessed May 2012]

17. http://www.iqwig.de/ [last accessed May 2012]

18. http://www.nice.org.uk/ [last accessed May 2012]

19. http://www.has-sante.fr/portail/jcms/c_240442/le-nice-liqwig-et-la-has-concluent-un-accord-de-cooperation [last accessed May 2012]

20. http://www.has-sante.fr/portail/jcms/c_412113/commission-de-la-transparence, as defined by Art. R163-15 to Art. R163-21 of the Social Security Code, http://www.legifrance.gouv.fr/affichCode.do;jsessionid=C901F8A4898090 34DAF6817E13C2273C.tpdjo07v_1?idSectionTA=LEGISCTA000006173276\&cidTexte=LEGITEXT00000607 $3189 \&$ dateTexte $=20100830$ [last accessed May 2012]

21. Art. L162-17 of the Social Security Code http:/www.legifrance.gouv.fr/affichCodeArticle.do?cidTexte=LEGIT EXT000006073189\&idArticle=LEGIARTI000020039241\&dateTexte $=$ and L5123-2 of the Public Health Code http://www.legifrance.gouv.fr/affichCodeArticle.do;jsessionid=95D2390DE3022CC0CF49921373FD520E.tpdj o15v_3?idArticle=LEGIARTI000006689963\&cidTexte=LEGITEXT000006072665\&dateTexte=20100828 [last accessed May 2012]

22. Art. L163-18 of the Social Security Code, http://www.legifrance.gouv.fr/affichCodeArticle.do;jsessionid=C901F8 A489809034DAF6817E13C2273C.tpdjo07v_1?idArticle=LEGIARTI000021662904\&cidTexte=LEGITEXT000 006073189\&dateTexte $=20100830$ [last accessed May 2012]

23. http://www.sante.gouv.fr/assurance_maladie/organisation/uncam.htm [last accessed May 2012]

24. http://www.ameli.fr/l-assurance-maladie/connaitre-1-assurance-maladie/missions-et-organisation/l-assurancemaladie/les-missions-de-la-cnamts.php [last accessed May 2012]

25. The LEEM (“Les Entreprises du Médicament") is the pharmaceutical companies' trade association in France, http:// www.leem.org/medicament/accueil.htm [last accessed May 2012]

26. http://www.conseil-national.medecin.fr/ [last accessed May 2012]

27. http://www.ordre.pharmacien.fr/ [last accessed May 2012]

28. Art. L162-61-1 of the Social Security Code, http:/www.legifrance.gouv.fr/affichCodeArticle.do?cidTexte=LEGIT EXT000006073189\&idArticle=LEGIARTI000020897495\&dateTexte=20100909 [last accessed May 2012]

29. Art. R163-5 of the Social Security Code, http://www.legifrance.gouv.fr/affichCodeArticle.do?cidTexte=LEGITEX 
T000006073189\&idArticle=LEGIARTI000006746711\&dateTexte=20100909 [last accessed May 2012]

30. Art. L162-16-4 of the Social Security Code, http://www.legifrance.gouv.fr/affichCodeArticle.do;jsessionid=5A0 1FF09C88782CD65E07B7B5DF9C877.tpdjo15v_3?cidTexte=LEGITEXT000006073189\&idArticle=LEGIART I000006740846\&dateTexte $=20100909 \&$ categorieLien $=$ cid\#LEGIARTI000006740846 [last accessed May 2012]

31. The CEPS assessed the impact that the reimbursement will have on the national objectives on health care spending ("Objectifs Nationaux des Dépenses d'Assurance Maladie”, ONDAM) which are budget restrictions aiming at cost-containment. The LFSS 2012 sets the ONDAM to 171,1 Mds E, around 2,5\% more than for 2011, http:// www.legifrance.gouv.fr/affichTexte.do?cidTexte=JORFTEXT000025005833\&dateTexte=\&categorieLien=id\# [last accessed May 2012]

32. Art. 6. b) of the Framework Agreement

33. Art. L162-16-4 of Social Security Code, http://www.legifrance.gouv.fr/affichCodeArticle.do;jsessionid=5A01F F09C88782CD65E07B7B5DF9C877.tpdjo15v_3?cidTexte=LEGITEXT000006073189\&idArticle=LEGIARTI 000006740846\&dateTexte $=20100909 \&$ categorieLien=cid\#LEGIARTI000006740846 [last accessed May 2012]

34. Art. L 162-17-4 of the Social Security Code, http://www.legifrance.gouv.fr/affichCode.do;jsessionid=A87DB7677 3CA682294A41C873B6601EA.tpdjo12v_3?idSectionTA=LEGISCTA000006172517\&cidTexte=LEGITEXT000 $006073189 \&$ dateTexte $=20110330$ [last accessed May 2012]

35. Art. L162-17-6 of the Social Security Code, http://www.legifrance.gouv.fr/affichCodeArticle.do;jsessionid=5A0 1FF09C88782CD65E07B7B5DF9C877.tpdjo15v_3?cidTexte=LEGITEXT000006073189\&idArticle=LEGIART I000006741371\&dateTexte=20100909\&categorieLien=cid\#LEGIARTI000006741371 [last accessed May 2012]

36. Art. 7c) of the Framework Agreement, providing that pharmaceuticals with an ASMR IV rating are eligible for this fast-track procedure under two additional conditions. The first one is that a comparative pharmaceutical exists and that the price notified is lower than or equal as the price of the comparative product. The second additional condition is that the pharmaceutical does not replace a generic product or a product which is going to be genericized

37. Art. 7d) of the Framework Agreement

38. CEPS, Annual Report 2009

39. Art. L162-17 of the Social Security Code, http://www.legifrance.gouv.fr/affichCodeArticle.do?cidTexte=LEGITE XT000006073189\&idArticle=LEGIARTI000020039241\&dateTexte [last accessed May 2012]

40. Decree n. 99-915 of October, 27 ${ }^{\text {th }}$ 1999, http://admi.net/jo/19991030/MESS9923357D.html [last accessed May 2012]

41. Decree of March, $18^{\text {th }}$ 2011, http://www.legifrance.gouv.fr/affichTexte.do?cidTexte=JORFTEXT000023759818\& dateTexte $=\&$ categorieLien $=$ id [last accessed May 2012]

42. Framework Agreement, Art. 17 and article L162-18 of the Social Security Code, http://www.legifrance.gouv.fr/ affichCodeArticle.do?cidTexte=LEGITEXT000006073189\&idArticle=LEGIARTI000017828244\&dateTexte [last accessed May 2012]

43. Art. L138-10 of the Social Security Code, modified by the Law n ${ }^{\circ} 2008-1330$ of December, $17^{\text {th }} 2008$, http://www. legifrance.gouv.fr/affichCodeArticle.do;jsessionid=ED9572F9F3297A88E51045E1D31EC436.tpdjo08v_2?cidT exte $=$ LEGITEXT000006073189\&idArticle=LEGIARTI000006740405\&dateTexte=20100913\&categorieLien $=$ ci d\#LEGIARTI000006740405 [last accessed May 2012]

44. Art. 18 of the Framework Agreement

45. Art. L162-17-4 of the Social Security Code modified by the Law n²009-879 of July, $21^{\text {st }} 2009$, http://www.legifrance.gouv.fr/affichCodeArticle.do?cidTexte=LEGITEXT000006073189\&idArticle=LEGIARTI000017828253\&d ateTexte $=$ and Art. R163-12 of the Social Security Code modified by Decree n²004-1398 of the 23rd of December 2004 [last accessed May 2012] http://legifrance.gouv.fr/affichTexteArticle.do?cidTexte=LEGITEXT00000607318 9\&idArticle=LEGIARTI000006746743[last accessed May 2012]

46. Art. L162-17-4 of the Social Security Code, http://www.legifrance.gouv.fr/affichCodeArticle.do?cidTexte=LEGIT EXT000006073189\&idArticle=LEGIARTI000017828253\&dateTexte $=[$ last accessed May 2012]

47. Decision of the UNCAM regarding the creation of a standard contract aiming at improving the practices of contracted physicians, March, $9^{\text {th }}$ 2009, http://www.legifrance.gouv.fr/affichTexte.do?cidTexte=JORFTEXT000020534299. [last accessed May 2012]

48. In December 2010, around 15.000 physicians signed a CAPI. Modifications of the scheme were brought by the Art.39 in the LFSS 2010. http://www.legifrance.gouv.fr/affichTexte.do?cidTexte=JORFTEXT000021528998\&da teTexte $=\&$ categorieLien $=\mathrm{id}$. [last accessed May 2012] 
49. Art. 3 and Annex 1 of the decision of the UNCAM, http://www.legifrance.gouv.fr/affichTexte.do?cidTexte=JORF TEXT000021528998\&dateTexte=\&categorieLien=id [last accessed May 2012]

50. Physicians having signed a CAPI earned around 3100 Euro in 2009 and targets were reached up to $45 \%$ in average. See "CAPI, $1^{\text {er }}$ résultats après une année d'exercice", Assurance-maladie, September 2010, available at http://www. ameli.fr/fileadmin/user_upload/documents/Dp_capi_16_09_2010_vdef.pdf [last accessed May 2012]

51. LFSS 2004, http://www.legifrance.gouv.fr/affichTexte.do?cidTexte=JORFTEXT000000249276\&dateTexte= [last accessed May 2012]

52. Plan Hôpital 2007. Available at: http://www.parhtage.sante.fr/re7/als/doc.nsf/VDoc/C1256B21004A6D5780256D A6003E3D90/\$FILE/h\%C3\%B4pital2007_mesures_0211.pdf [last accessed May 2012]

53. Decree of the $16^{\text {th }}$ of June 2004, http://www.legifrance.gouv.fr/affichTexte.do?cidTexte=JORFTEXT0000002511 $71 \&$ dateTexte $=$.and regular updates which are made in the Art. L 5126-4 of the Public Health Code, http://www. legifrance.gouv.fr/affichCodeArticle.do;jsessionid=1931267969CC6F47D2D917B892140995.tpdjo14v_2?idArticle $=$ LEGIARTI000006690077\&cidTexte $=$ LEGITEXT000006072665\&dateTexte $=20090122$ [last accessed May 2012]

54. "Plan Hôpital 2007”, http://www.parhtage.sante.fr/re7/als/doc.nsf/VDoc/C1256B21004A6D5780256DA6003E3D 90/\$FILE/h\%C3\%B4pital2007_mesures_0211.pdf. Each patient is classified in a "Groupe Homogène de Malades“" (GHM). Each GHM is associated with a "Groupe Homogène de Séjour" (GHS) which is the basis of the reimbursement for hospitals. Further information is available on the website of the Health Ministry, http://www.sante.gouv. fr/IMG/pdf/Presentation_des_grands_lignes_de_la_reforme.pdf [last accessed May 2012]

55. Decree n. 2004-546 of June, $15^{\text {th }}$ 2004, http://www.legifrance.gouv.fr/affichTexte.do?cidTexte=JORFTEXT00000 0251171\&dateTexte=, Art. L5126-4 of the Social Security Code regarding the inscription on the retrocession list, http://www.legifrance.gouv.fr/affichCodeArticle.do;jsessionid=49C4CFEA499207086425B67770B2F295.tpdjo0 $4 \mathrm{v} \_1$ ?cidTexte $=$ LEGITEXT000006072665\&idArticle $=$ LEGIARTI000006690074\&dateTexte $=\&$ categorieLien $=\mathrm{c}$ id and the art. R5126-102 to R5126-110 of the Public Health Code regarding the provisions applying to hospital ambulatory medicines, http://www.legifrance.gouv.fr/affichCodeArticle.do?cidTexte=LEGITEXT000006073189 \&idArticle=LEGIARTI000020039247\&dateTexte $=$ [last accessed May 2012]

56. Art. L162-16-5 of the Social Security Code, http:/www.legifrance.gouv.fr/affichCodeArticle.do?cidTexte=LEGIT EXT000006073189\&idArticle $=$ LEGIARTI000020039247\&dateTexte $=$ [last accessed May 2012]

57. Art. 8 of the Framework Agreement

58. Decree of April, 27th 2009, the flat-rate mark-up is set to 22 euro since January 2010

59. Art. R5126-110 of the Public Health Code, http://www.legifrance.gouv.fr/affichCodeArticle.do;jsessionid=1EC14 254F3F3C5F1DAF047FED1A19D1D.tpdjo04v_1?idArticle=LEGIARTI000006915453\&cidTexte=LEGITEXT0 $00006072665 \&$ dateTexte $=20090130$ [last accessed May 2012]

60. Art. R5126-110 of the Public Health Code, http://www.legifrance.gouv.fr/affichCodeArticle.do;jsessionid=1EC 14254F3F3C5F1DAF047FED1A19D1D.tpdjo04v_1?idArticle=LEGIARTI000006915453\&cidTexte=LEGITE XT000006072665\&dateTexte $=20090130$ and the Art. 10 of the Framework Agreement [last accessed May 2012]

61. Art. L162-22-7 of the Social Security Code, http://www.legifrance.gouv.fr/affichCodeArticle.do;jsessionid=CCEA 409F2A7230017CACF66FBE58B727.tpdjo11v_3?idArticle=LEGIARTI000019954067\&cidTexte=LEGITEXT0 $00006073189 \&$ dateTexte $=20100225$ [last accessed May 2012]

62. Art. D162-13 of the Social Security Code, http://www.legifrance.gouv.fr/affichCodeArticle.do?cidTexte=LEGITEX T000006073189\&idArticle=LEGIARTI000006735368\&dateTexte=\&categorieLien=cid [last accessed May 2012]

63. Art. R5121-68 to R.5121-76 of the Public Health Code, http://www.legifrance.gouv.fr/affichCode.do;jsessionid=6 A700D08E4FEC6197E4A6180747A0CE9.tpdjo15v_1?idSectionTA=LEGISCTA000006196546\&cidTexte=LEG ITEXT000006072665\&dateTexte=20110203 [last accessed May 2012].

64. Art. L162-16-5-1 of the Social Security Code, http://www.legifrance.gouv.fr/affichCodeArticle.do;jsessionid=FE2 AFAC5F23036B11ED39ED479F3B23F.tpdjo15v_1?cidTexte=LEGITEXT000006073189\&idArticle=LEGIARTI $000006741362 \&$ dateTexte $=20081127 \&$ categorieLien $=$ cid [last accessed May 2012]

65. Decree n. 99-915 of October, $27^{\text {th }}$ 1999, http://legifrance.gouv.fr/affichTexte.do;jsessionid=FDFCF202BCDFDA 2015F5269A89054CCE.tpdjo13v_2?cidTexte=JORFTEXT000000384938\&dateTexte=20091210 [last accessed May 2012]

66. Art. R163-3 of the Social Security Code, modified by Decree n. 2004-1398 of December, 23 ${ }^{\text {rd }} 2004$, http://www. legifrance.gouv.fr/affichCodeArticle.do;jsessionid=1B63C94B47687D07E7EF0C2FC8183BC9.tpdjo04v_2?cidT exte $=$ LEGITEXT000006073189\&idArticle $=$ LEGIARTI000006746697\&dateTexte $=20100910 \&$ categorieLien $=\mathrm{ci}$ d\#LEGIARTI000006746697 [last accessed May 2012] 
67. Art. R163-18 of the Social Security Code, http://www.legifrance.gouv.fr/affichCodeArticle.do;jsessionid=95066 53663F98C254E6CA4CD23EEB1B9.tpdjo10v_1?cidTexte=LEGITEXT000006073189\&idArticle=LEGIARTI 000006747677\&dateTexte=20100910\&categorieLien=cid\#LEGIARTI000006747677 [last accessed May 2012]

68. HAS, Annual Report 2010, available at http://www.has-sante.fr/portail/jcms/c_1070437/la-haute-autorite-de-santepublie-son-rapport-annuel-dactivite-2010 [last accessed May 2012]

69. Art. R163-6 of the Social Security Code, http://www.legifrance.gouv.fr/affichCodeArticle.do?cidTexte=LEGITEX T000006073189\&idArticle=LEGIARTI000006747689\&dateTexte=\&categorieLien=cid [last accessed May 2012]

70. More information can be found at http://www.afssaps.fr/content/download/34495/451283/version/1/file/PointInformation-ReevaluationBeneficesRisques.pdf [last accessed May 2012]

71.http://www.has-sante.fr/portail/upload/docs/application/pdf/2010-11/presentation_commission_evaluation_ economique_sante_publique.pdf [last accessed May 2012]

72. For more information regarding the missions of the CEESP, see bylaws of the CEESP, http://www.sante.gouv.fr/ fichiers/bo/2008/08-09/ste_20080009_0100_0139.pdf [last accessed May 2012]

73. The principles of medico-economic studies by the HAS were enshrined in the law with the art. 47 of the LFSS 2012, http://www.assemblee-nationale.fr/13/ta/ta0777.asp [last accessed May 2012]

74. La lettre d'information de la Haute Autorité de Santé, May-July 2010

75. The public consultation “L'évaluation économique à la Haute Autorité de Santé - Principes et méthodes”, http://www. has-sante.fr/portail/upload/docs/application/pdf/2010-11/levaluation_economique_a_la_haute_autorite_de_sante. pdf [last accessed May 2012]

76. Art.48 of the LFSS 2012, http://www.assemblee-nationale.fr/13/ta/ta0777.asp [last accessed May 2012]

77. Amphis de la Santé, $10^{\text {th }}$ January 2012 on the topic "Price of medicinal products in France: a new deal?".

78. Regulatory Affairs Journal Pharma, “The lure of orphan products”, P. Charlish, $6^{\text {th }}$ of September 2010

79. Pharmaceutiques, May 2009, Noël Renaudin: Stop à la flambée des prix, http://www.pharmaceutiques.com/archive/ une/art_1234.html [last accessed May 2012]

80. Art.29 of the LFSS 2011, http://www.legifrance.gouv.fr/affichTexte.do?cidTexte=JORFTEXT000023261006\&da teTexte $=\&$ categorieLien $=$ id [last accessed May 2012]

81. Art.26 of the law, http://www.assemblee-nationale.fr/13/ta/ta0805.asp [last accessed May 2012]

82. Art. 18,21 and 31 of the law

83. Art. 27 of the law

84. Art. 30 of the law

85. Sharma V. EFPIA calls for new debate on drug pricing. Regulatory Affairs Journal Pharma 2010; June, 22 ${ }^{\text {nd }}$

86. Hutchings A. Rewarding innovation? An assessment of the factors that affect price and reimbursement status in Europe. Journal of Medical Marketing 2010; 10 